\title{
Relationship between Nutrition Knowledge, Consumption Pattern and Physical Activity, and Body Image in Students during the Covid-19 Pandemic Hubungan Antara Pengetahuan Gizi, Pola Konsumsi, dan Aktivitas Fisik dengan Body Image pada Mahasiswa di Masa Pandemi Covid-19
}

\section{Crifianny P. Wenas, ${ }^{1}$ Alexander S. L. Bolang, ${ }^{2}$ Carla F. Kairupan}

\author{
${ }^{1}$ Program Studi Magister Ilmu Kesehatan Masyarakat Program Pascasarjana Universitas Sam \\ Ratulangi, Manado, Indonesia \\ ${ }^{2}$ Bagian Biokimia Fakultas Kedokteran Universitas Sam Ratulangi, Manado, Indonesia \\ ${ }^{3}$ Bagian Patologi Anatomi Fakultas Kedokteran Universitas Sam Ratulangi, Manado, Indonesia \\ Email: crifiannywenas1111@student.unsrat.ac.id \\ Received: December 12, 2021; Accepted: January 26, 2022; Published on line: January 28, 2022
}

\begin{abstract}
Body image is an individual's experience in the form of perception of his/her body shape and weight as well as behavior that leads to the individual's evaluation of physical appearance. This study aimed to determine the relationship between nutritional knowledge, consumption pattern and physical activity, and the body image of students in the Covid-19 pandemic. This was a quantitative study with an analytical observational design using a cross sectional approach. Respondents were all students of Geothermal Specialization the Geothermal Specialization Department of Physics, Faculty of Mathematics and Natural Sciences at Manado State University totaling 88 people. The study instrument was in the form of questionnaire made into google form. The results showed that 71 respondents $(80.7 \%)$ had a positive body image. The bivariate analysis using chi-square test showed a significant relationship between body image and nutritional knowledge $(\mathrm{p}=0.046)$, consumption pattern $(\mathrm{p}=0.000)$, and physical activity $(0.014)$. Multivariate analysis using logistic regression showed that physical activity was the variable having most dominant relationship with body image (OR 3,245; 95\% CI 1,239-8,502). In conclusion, there is a significant relationship between nutritional knowledge, consumption pattern, physical activity, and the body image of students in the Covid-19 pandemic. Physical activity is the most related factor with body image.
\end{abstract}

Keywords: body image; nutritional knowledge; consumption pattern; physical activity

\begin{abstract}
Abstrak: Body image merupakan pengalaman individu berupa persepsi terhadap bentuk dan berat tubuhnya, serta perilaku yang mengarah pada evaluasi individu tersebut terhadap penampilan fisik. Penelitian ini bertujuan untuk mengetahui hubungan antara pengetahuan gizi, pola konsumsi dan aktivitas fisik dengan body image mahasiswa pada masa pandemi Covid-19. Metode penelitian yaitu kuantitatif dengan rancangan observasional analitik dan desain potong lintang. Responden yaitu seluruh mahasiswa Peminatan Geotermal Jurusan Fisika Fakultas MIPA Universitas Negeri Manado berjumlah 88 orang. Instrumen penelitian berupa kuesioner, dibuat dalam bentuk google form. Hasil penelitian mendapatkan $80,7 \%$ responden memiliki body image positif. Hasil analisis bivariat dengan uji chi-square menunjukkan hubungan bermakna antara body image dengan pengetahuan gizi $(\mathrm{p}=0,046)$, pola konsumsi $(\mathrm{p}=0,000)$, dan aktivitas fisik $(\mathrm{p}=0,014)$. Analisis multivariat menggunakan regresi logistik mendapatkan bahwa aktivitas fisik merupakan variabel yang memiliki hubungan paling dominan dengan body image (OR 3,245; 95\% CI 1,239-8,502). Simpulan penelitian ini ialah terdapat hubungan antara pengetahuan gizi, pola konsumsi, dan aktivitas fisik dengan body image mahasiswa pada masa pandemi Covid-19. Aktivitas fisik merupakan faktor yang paling berhubungan dengan body image.

Kata kunci: body image; pengetahuan gizi; pola konsumsi; aktivitas fisik
\end{abstract}




\section{PENDAHULUAN}

Body image merupakan pengalaman individu berupa persepsi terhadap bentuk dan berat tubuhnya, serta perilaku yang mengarah pada evaluasi individu tersebut terhadap penampilan fisiknya. ${ }^{1}$ Permasalahan mengenai body image terjadi baik pada pria maupun wanita dan mengikuti stereotipe dimana wanita merasa tertekan untuk tampil lebih kurus dan feminin sedangkan pria ingin terlihat kuat dan maskulin. Memiliki body image negatif merupakan salah satu penyebab utama terjadinya gangguan makan seperti anoraksia, bulimia, ortorexia, compulsive overeating, dan binge eating disorder. ${ }^{2}$ Mahasiswa khususnya sangat rentan dengan informasi dari media mengenai diet dan bentuk tubuhnya. Penelitian pada mahasiswa di Padang, mendapatkan bahwa $87 \%$ responden memiliki body image negatif yang mengasumsikan bahwa pandangan terhadap tubuh atau body image di kalangan mahasiswa merupakan hal penting yang perlu diperhatikan. ${ }^{3}$

Pengetahuan gizi merupakan salah satu faktor yang memengaruhi pandangan terhadap body image. Memiliki pengetahuan mendalam mengenai gizi dapat meningkatkan body image seseorang. Mengetahui zat gizi dalam makanan dan kaitannya dengan pertumbuhan, kesehatan, dan penyakit dapat mendorong seseorang untuk memiliki body image yang lebih positif. Jika memiliki pengetahuan gizi yang baik, maka seseorang diharapkan dapat lebih memperhatikan asupan makanan yang bergizi dan seimbang untuk tubuh sehingga dapat juga menyebabkan perubahan persepsi negatif terhadap bentuk tubuhnya. ${ }^{4-6}$

Pola konsumsi memiliki peran penting terhadap body image dalam arti bahwa pola konsumsi dapat memengaruhi bentuk dan struktur tubuh sehingga berkaitan dengan cara pandang atau persepsi terhadap tubuh. Penelitian mengenai body image, pola makan dan kesehatan mental mahasiswa di Ghana, melaporkan adanya hubungan antara pola makan dan body image. Hasil ini menunjukkan bahwa saat mereka dapat mengendalikan pola makan maka terdapat perasaan puas dengan body image-nya. Sebaliknya, jika tidak dapat mengendalikan pola makan dapat berakibatkan body image yang negatif. ${ }^{7}$ Aktivitas fisik juga dapat memberikan efek yang baik dalam meningkatkan body image positif, terlebih dari itu aktivitas fisik dapat menghambat pembentukan body image negatif pada mahasiswa. ${ }^{8}$ Hasil penelitian mendapatkan bahwa aktivitas fisik dan body image berhubungan erat. Individu yang melakukan aktivitas fisik secara jangka panjang memiliki body image yang lebih baik daripada yang tidak beraktivitas fisik. ${ }^{9}$

Pada tanggal 11 Maret 2020, WHO menetapkan Coronavirus Disease 2019 (Covid-19) sebagai pandemi. Indonesia melaporkan kasus pertama Covid-19 pada tanggal 2 Maret 2020 dengan peningkatan kasus terus terjadi dengan penyebaran yang sangat cepat di seluruh wilayah Indonesia. Di masa pandemi ini, mahasiswa yang biasanya berkuliah secara tatap muka dituntut untuk melakukan perkuliahan secara online. ${ }^{10,11}$ Pembatasan yang dilakukan selama pandemi Covid-19 menyebabkan perubahan terhadap rutinitas serta gaya hidup sehingga dapat memengaruhi kebiasan makan, perilaku olahraga, serta body image secara bermakna. ${ }^{12,13}$

Hasil observasi awal serta wawancara penulis dengan mahasiswa Peminatan Geotermal Jurusan Fisika Fakultas MIPA Universitas Negeri Manado, mendapatkan bahwa di masa pandemi ini sebagai kelompok yang juga terdampak pandemi COVID-19 mengalami perubahan bermakna terhadap rutinitas. Kegiatan turun lapangan yang biasanya dilakukan rutin oleh mahasiswa harus ditiadakan dan diganti dengan kuliah online selama masa pandemi. Selain itu, sebagian besar mahasiswa yang kembali ke rumah keluarga merasakan perubahan dalam hal pola konsumsi yang lebih teratur. Untuk mahasiswa yang memilih tetap berada di sekitar daerah kampus juga merasakan perbedaan dalam rutinitas, yaitu aktivitas fisik menjadi berkurang.

\section{METODE PENELITIAN}

Penelitian ini menggunakan metode 
penelitian kuantitatif dengan rancangan observasional analitik dan desain potong lintang. Penelitian ini dilaksanakan di bagian Peminatan Geotermal Jurusan Fisika Fakultas MIPA Universitas Negeri Manado pada bulan April-November 2021. Total populasi yaitu 88 responden. Variabel bebas terdiri dari pengetahuan gizi, pola konsumsi, dan aktivitas fisik sedangkan variabel terikat yaitu body image.

Instrumen yang digunakan yaitu kuesioner pengetahuan gizi yang sudah diuji validitas dan reliabilitas, kuesioner pola konsumsi yang diambil dari penelitian oleh Tobelo et $\mathrm{al}^{14}$ yaitu Global Physical Activity Questionnaire (GPAQ) untuk mengukur aktivitas fisik, serta kuesioner body image yang dibuat berdasarkan kuesioner Multidimensional Body Image Self Relation QuestionnaireApperance Scales (MBSRQ-AS) diambil dari penelitian Gimon et al. ${ }^{15}$ Pengambilan data dilakukan dengan menyebarkan kuesioner dalam bentuk google form secara daring melalui Whatsapp grup mahasiswa.

\section{HASIL PENELITIAN}

Hasil penelitian sesuai dengan teknik analisis univariat, bivariat, dan multivariat serta pengelolaan data hasil ditampilkan dalam bentuk tabel. Tabel 1 memperlihatkan distribusi responden berdasarkan karakteristik. Reponden penelitian berjenis kelamin perempuan lebih banyak daripada laki-laki $(53,4 \%$ vs $46,6 \%)$. Mayoritas responden berusia 19 tahun $(81,4 \%)$. Responden terbanyak berada di semester 9 yaitu 25 responden $(28,4 \%)$. Status gizi responden terbanyak pada kategori normal $(50 \%)$.

Tabel 2 memperlihatkan bahwa bahwa terdapat lebih banyak responden yang memiliki pengetahuan gizi cenderung baik, yakni dengan kategori cukup berjumlah 37 responden $(42 \%)$. Selain itu lebih banyak responden termasuk dalam pola konsumsi kategori cukup $(68,2 \%)$, sedangkan untuk aktivitas fisik, terdapat lebih banyak responden yang termasuk kategori sedang $(53,4 \%)$. Hasil penelitian ini juga menunjukkan bahwa sebagian besar responden memiliki body image postitif yaitu sebanyak 71 responden $(80,7 \%)$.
Tabel 1. Distribusi responden berdasarkan karakteristik

\begin{tabular}{lcc}
\hline $\begin{array}{c}\text { Karakteristik } \\
\text { Responden }\end{array}$ & $\mathbf{N}$ & $\%$ \\
\hline Jenis kelamin & & \\
Laki-laki & 41 & 46.6 \\
Perempuan & 47 & 53.4 \\
Usia & & \\
18 tahun & 13 & 14.8 \\
19 tahun & 19 & 81.4 \\
20 tahun & 15 & 17 \\
21 tahun & 17 & 19.3 \\
22 tahun & 14 & 15.9 \\
23 tahun & 10 & 11.4 \\
Semester & & \\
1 & 11 & 12.5 \\
3 & 13 & 14.8 \\
5 & 20 & 22.7 \\
7 & 13 & 14.8 \\
9 & 25 & 28.4 \\
11 & 6 & 6.8 \\
Status gizi & & \\
Underweight & 16 & 18.2 \\
Normal & 44 & 50 \\
Overweight & 17 & 19.3 \\
Obesitas I & 9 & 10.2 \\
Obesitas II & 2 & 2.3 \\
\hline
\end{tabular}

Analisis bivariat dilakukan dengan menggunakan uji chi-square. Tabel 3 memperlihatkan bahwa semua responden yang memiliki pengetahuan gizi baik sejumlah 14 mahasiswa memiliki body image positif, dengan nilai $\mathrm{p}=0,046(\mathrm{p}<0,05)$ yang menunjukkan bahwa terdapat hubungan bermakna antara pengetahuan gizi dengan body image. Terdapat sebanyak 55 responden $(91,7 \%)$ dengan pola konsumsi cukup memiliki body image positif, dengan nilai $\mathrm{p}=0,000(\mathrm{p}<0,05)$ yang menunjukkan adanya hubungan bermakna antara kedua variabel tersebut. Responden dengan aktivitas fisik tinggi sejumlah 20 mahasiswa $(95,2 \%)$ memiliki body image positif. Demikian pula dengan responden yang masuk dalam kategori aktivitas fisik sedang, sebanyak $83 \%$ memiliki body image positif dengan nilai $\mathrm{p}=0,014$ $(\mathrm{p}<0,05)$ yang menunjukkan terdapat hubungan bermakna antara kedua variabel yang diuji. Variabel aktivitas fisik merupakan variabel yang memiliki hubungan paling erat dengan body image, dengan nilai 
44 e-CliniC, Volume 10, Nomor 1, Januari-Juni 2022, hlm. 41-49

Tabel 2. Distribusi variabel penelitian

\begin{tabular}{llcc}
\hline \multicolumn{1}{c}{ Variabel Penelitian } & Kategori & n & \% \\
\hline Pengetahuan gizi & Baik & 14 & 14,9 \\
& Cukup & 37 & 42 \\
& Kurang & 37 & 42 \\
Pola konsumsi & Baik & 15 & 17 \\
& Cukup & 60 & 68,2 \\
\multirow{4}{*}{ Aktivitas fisik } & Kurang & 13 & 14,8 \\
& Tinggi & 21 & 23,9 \\
Body image & Sedang & 47 & 53,4 \\
& Rendah & 20 & 22,7 \\
& Positif & 71 & 80,7 \\
& Negatif & 17 & 19,3 \\
\hline
\end{tabular}

Tabel 3. Hasil uji statistik chi-square

\begin{tabular}{|c|c|c|c|c|c|c|c|c|c|}
\hline \multicolumn{2}{|c|}{ Variabel } & \multicolumn{6}{|c|}{ Body image } & \multirow[t]{3}{*}{ Nilai $p$} & \multirow[t]{3}{*}{ OR } \\
\hline \multirow[t]{2}{*}{ Bebas } & \multirow[t]{2}{*}{ Terikat } & \multicolumn{2}{|c|}{ Positif } & \multicolumn{2}{|c|}{ Negatif } & \multicolumn{2}{|c|}{ Total } & & \\
\hline & & $\mathrm{n}$ & $\%$ & $\mathrm{n}$ & $\%$ & $\mathrm{n}$ & $\%$ & & \\
\hline \multirow{3}{*}{$\begin{array}{l}\text { Pengetahuan } \\
\text { Gizi }\end{array}$} & Baik & 14 & 100 & 0 & 0 & 14 & 100 & \multirow{3}{*}{0,046} & \multirow{3}{*}{2,699} \\
\hline & Cukup & 31 & 83.8 & 6 & 16.2 & 37 & 100 & & \\
\hline & Kurang & 26 & 70.3 & 11 & 29.7 & 37 & 100 & & \\
\hline \multirow[t]{3}{*}{ Pola Konsumsi } & Baik & 12 & 80 & 3 & 20 & 15 & 100 & \multirow{3}{*}{0,000} & \multirow{3}{*}{2,864} \\
\hline & Cukup & 55 & 91.7 & 5 & 8.3 & 60 & 100 & & \\
\hline & Kurang & 4 & 30.8 & 9 & 69.2 & 13 & 100 & & \\
\hline \multirow[t]{3}{*}{ Aktivitas Fisik } & Tinggi & 20 & 95.2 & 1 & 4.8 & 21 & 100 & \multirow{3}{*}{0,014} & \multirow{3}{*}{3,245} \\
\hline & Sedang & 39 & 83 & 8 & 17 & 47 & 100 & & \\
\hline & Rendah & 12 & 60 & 8 & 40 & 20 & 100 & & \\
\hline
\end{tabular}

OR 3,245 yang berarti responden dengan aktivitas fisik yang baik berpeluang 3,2 kali lebih besar untuk memiliki body image positif dibandingkan responden yang masih kurang melakukan aktivitas fisik.

\section{BAHASAN}

Responden dalam penelitian ini yaitu seluruh mahasiswa Peminatan Geotermal Universitas Negeri Manado yang memenuhi kriteria inklusi, yakni setuju menjadi responden serta berusia di atas 18 tahun. Distribusi frekuensi usia responden yaitu 18-23 tahun, dimana menurut Depkes RI klasifikasi usia untuk masa remaja akhir yaitu 17-25 tahun, ${ }^{16}$ sehingga seluruh mahasiswa yang menjadi responden dalam penelitian ini termasuk dalam klasifikasi masa remaja akhir. Pada usia remaja terjadi perubahan yang berkaitan dengan pertumbuhan dan perkembangan fisik dan kognitif yang dapat mempengaruhi body image.

Karakteristik responden berdasarkan jenis kelamin menunjukkan bahwa terdapat lebih banyak responden dengan jenis kelamin perempuan pada penelitian ini. Kemudian didapatkan bahwa dari responden yang memiliki body image negatif, lebih banyak di antaranya berjenis kelamin perempuan. Body image lebih sering dikaitkan sebagai masalah di kalangan perempuan, dimana pengaruh sosial membuat standar tertentu yang dianggap ideal dan berhubungan dengan ketidakpuasan body image pada perempuan dibandingkan laki-laki. Namun, menurut Ricciardelli dan Yager $^{17}$ masalah yang berkaitan 
dengan body image dapat terjadi baik pada perempuan maupun laki-laki.

Berdasarkan status gizi yang diukur dengan Indeks Massa Tubuh (IMT), didapatkan bahwa sebagian besar responden memiliki status gizi normal. Jika dihubungkan dengan body image maka status gizi dapat berpengaruh terhadap body image seseorang; hal ini berkaitan dengan fokus perhatian pada masa remaja yaitu penilaian terhadap tubuh dan penampilan fisik yang dapat mengubah persepsi seseorang akan body image-nya.

Hasil penelitian ini menunjukkan bahwa seluruh responden dengan pengetahuan gizi baik memiliki body image positif, dan sebagian besar responden yang memiliki body image negatif merupakan responden yang termasuk dalam kategori pengetahuan gizi kurang. Penelitian yang dilakukan oleh Ardhyarini dan Avissa ${ }^{18}$ pada remaja putri di Cimahi, menyimpulkan bahwa pendidikan gizi dapat berpengaruh terhadap pengetahuan gizi yang juga memengaruhi persepsi body image. Hal ini sesuai dengan penelitian oleh Marjan ${ }^{19}$ yang menyatakan bahwa terdapat hubungan antara pengetahuan gizi dengan persepsi body image pada remaja di Kota Tangerang. Sejalan dengan penelitian ini yaitu penelitian oleh Hyun et $\mathrm{al}^{20}$ pada siswa di Korea dan China, yang mendapatkan adanya hubungan bermakna antara pengetahuan gizi dengan kepuasan body image pada remaja di Korea $(\mathrm{r}=0,208$, $\mathrm{p}<0,01)$ namun sebaliknya, tidak terdapat hubungan antara kedua variabel tersebut pada remaja di China.

Ketika meneliti tentang persepsi body image mahasiswa, tersirat bahwa perilaku berisiko yang dipraktikkan berasal dari kurangnya pengetahuan tentang gizi. ${ }^{21} \mathrm{Hal}$ ini dapat dikaitkan dengan teori bahwa salah satu dasar pembentukkan suatu persepsi yaitu melalui pengetahuan yang dimiliki. Persepsi dibentuk berdasarkan apa yang kita ketahui, dengan demikian persepsi merupakan sebuah efek dari kombinasi informasi yang diterima sistem sensorik dan pengalaman serta pengetahuan yang dipelajari. Munculnya suatu persepsi baik positif maupun negatif tergantung pada bagaimana cara individu menggambarkan pengetahuannya tentang objek yang dipersepsi. ${ }^{22,23}$

Penelitian oleh Li dan $\mathrm{Liu}^{24}$ melaporkan bahwa penggunaan media sosial yang berkaitan dengan literasi kesehatan dapat memengaruhi perilaku preventif seseorang selama masa pandemi Covid-19. Masa pandemi ini mengakibatkan adanya peningkatan penyebaran informasi mengenai imunitas dan kesehatan secara umum, sehingga informasi mengenai gizi pun dapat lebih mudah diakses bahkan dengan banyaknya komersial maupun video dan gambar yang dibuat untuk tujuan pembelajaran, memungkinkan seseorang untuk mendapatkan pengetahuan mengenai gizi dengan mudah. Terlebih usia remaja yang cenderung banyak menggunakan atau mengakses media sosial sehingga lebih sering menemukan informasi mengenai gizi yang dapat meningkatkan pengetahuan gizi mereka sehingga juga dapat memengaruhi terbentuknya persepsi body image yang lebih positif.

Berdasarkan hasil penelitian ini, didapatkan 54 responden dari total 60 responden yang termasuk kategori pola konsumsi cukup juga memiliki body image positif, sedangkan dari 13 responden yang pola konsumsinya kurang, sembilan diantaranya memiliki body image negatif. Hasil penelitian ini sejalan dengan penelitian yang dilakukan Tan dan Ibrahim $^{25}$ pada remaja putri di Batam. Hasil uji statistik memperoleh nilai $p=0,000(p<0,005)$ sehingga dapat disimpulkan bahwa terdapat hubungan antara body image dengan pola konsumsi, dimana dipaparkan juga bahwa responden yang pola konsumsinya buruk dan memiliki body image negatif mencakup sebagian besar responden yaitu sebanyak 37 responden $(82,2 \%) .{ }^{25}$ Penelitian oleh Asnuddin dan Sanjaya ${ }^{26}$ juga menunjukkan adanya hubungan bermakna dengan nilai $p=0,025$ $(\mathrm{p}<0,005)$ dimana responden yang memiliki pola konsumsi baik berpeluang memiliki body image positif.

Beberapa penelitian melaporkan adanya korelasi antara pola makan dengan harga diri seseorang, antara lain penelitian oleh Kaloeti dan Ardhiani ${ }^{27}$ serta Koftidou et $\mathrm{al}^{28}$ yang mendapatkan adanya hubungan 
kuat antara harga diri dengan pola makan yaitu jika memiliki pola makan yang tidak sehat maka cenderung menimbulkan harga diri yang lebih rendah. Kurangnya harga diri merupakan masalah yang dihadapi oleh banyak individu di berbagai titik dalam hidup mereka. Masa remaja merupakan masa yang menantang dan penuh dengan penyesuaian diri terhadap perubahan dengan gaya hidup, karir, akademik, dan tubuh sehingga remaja mendapatkan kesulitan dengan harga diri mereka. Harga diri yang rendah sering dikaitkan dengan tingginya ketidakpuasan terhadap tubuh, sebaliknya memiliki harga diri yang lebih baik dapat berpengaruh pada pembentukan persepsi body image yang lebih positif. ${ }^{29-31}$ Terdapat beberapa faktor yang dapat memengaruhi terbentuknya body image yang positif, seperti apresiasi, penerimaan dari orang lain, menemukan orang lain yang menerima dirinya apa adanya, konsep yang luas mengenai kecantikan, positivitas yang memiliki efek terhadap penampilan luar, dan salah satu yang paling penting yaitu merawat tubuh melalui perilaku kesehatan yang baik. Memiliki pola konsumsi yang baik merupakan salah satu perilaku kesehatan yang perlu dilakukan dalam upaya untuk meningkatkan kesehatan secara umum, yang mencakup baik kesehatan tubuh maupun kesehatan mental. ${ }^{32}$

Masa pandemi Covid-19 menyebabkan berbagai perubahan terutama pada gaya hidup masyarakat, tidak terkecuali pola konsumsi. Perubahan ini disebabkan adanya kebijakan untuk tetap berada di rumah dan membatasi kegiatan di luar rumah, juga berlaku pada mahasiswa yang dialihkan untuk melakukan perkuliahan secara online. Hasil penelitian ini menunjukkan bahwa lebih banyak responden yang memiliki pola konsumsi cenderung baik. Hal ini dapat disebabkan oleh anjuran dari pemerintah untuk memperhatikan konsumsi makanan terutama di masa pandemi ini, dengan membuat Pedoman Gizi Seimbang di masa pandemi Covid-19. Selain itu, terdapat kesadaran dari masyarakat untuk lebih menjaga pola makan untuk meningkatkan imunitas agar dapat terlindung dari virus
Covid-19. Dengan diadakannya perkuliahan online juga membuat sebagian besar mahasiswa untuk kembali ke rumah keluarga, sehingga dapat memiliki pola konsumsi yang lebih teratur dibandingkan jika berada di tempat kost.

Hasil penelitian ini menunjukkan bahwa sebagian besar responden yang melakukan aktivitas fisik berat juga memiliki body image positif, begitu pun dengan responden yang termasuk dalam kategori aktivitas fisik sedang dan rendah juga sebagian besar di antaranya memiliki body image positif. Penelitian ini sejalan dengan penelitian oleh Maracilu $^{33}$ yang melakukan uji statistik dengan chi-square dan mendapatkan hasil nilai $\mathrm{p}=0,031(\mathrm{p}<0,05)$ yang menunjukkan bahwa terdapat hubungan bermakna antara aktivitas fisik dengan body image. Penelitian ini juga didukung oleh hasil penelitian Atmaja $^{34}$ di Surakarta yang menunjukkan adanya korelasi yang cukup antara aktivitas fisik dengan body image pada responden laki-laki dan korelasi yang kuat pada responden perempuan.

Bukti ilmiah menunjukkan bahwa kesenangan berolahraga berhubungan positif dengan perubahan body image. Partisipasi dalam aktivitas fisik dan olahraga berkaitan dengan berkurangnya body image negatif dan sebaliknya terjadi peningkatan body image positif. Dalam kategori kesejahteraan psikologis, persepsi, pandangan dan perasaan yang berkaitan dengan kondisi kesehatan, harga diri, dan body image sebagian besar dapat ditingkatkan melalui aktivitas fisik. Secara umum, melakukan aktivitas fisik memiliki dampak positif, dimana dapat terjadi penurunan terhadap body image negatif. ${ }^{35-37}$

Menurut data yang diperoleh, sebagian besar responden melakukan aktivitas fisik maupun aktivitas rekreasi dengan intensitas sedang dan hanya terdapat beberapa responden yang melakukan aktivitas fisik dengan berjalan kaki atau bersepeda untuk bepergian. Hal ini dapat dikaitkan dengan kondisi pandemi Covid-19 yang menyebabkan perubahan kegiatan perkuliahan menjadi online dan terdapat kebijakan untuk mengurangi kegiatan di luar rumah sehingga menyebab- 
kan berkurangnya aktivitas fisik seperti berjalan dan bersepeda. Dalam penelitian ini didapatkan lebih banyak responden yang termasuk dalam kategori aktivitas sedang yaitu sebanyak 47 responden $(53,4 \%)$. Melakukan aktivitas fisik sedang berarti telah mempraktikkan rekomendasi WHO mengenai aktivitas fisik bagi orang dewasa. Selain itu juga telah memenuhi anjuran pemerintah untuk melakukan aktivitas fisik secara teratur sebagai salah satu pilar dari Pedoman Gizi Seimbang. Responden penelitian ini merupakan mahasiswa Peminatan Geotermal Universitas Negeri Manado yang sebagian besar kegiatan perkuliahan berfokus pada kegiatan turun lapangan.

Berdasarkan wawancara awal penulis dengan beberapa mahasiswa, didapatkan bahwa dengan diberlakukannya kuliah online di masa pandemi ini, terdapat perubahan besar terhadap rutinitas mahasiswa termasuk berkurangnya aktivitas fisik yang dilakukan. Namun berdasarkan hasil jawaban responden pada kuesioner dapat diketahui bahwa walaupun aktivitas fisik dalam kategori perjalanan ke tempat aktivitas berkurang, namun sebagian besar responden tetap aktif melakukan aktivitas fisik baik secara rutin sebagai aktivitas yang dilakukan di rumah maupun aktivitas rekreasi, dengan intensitas sedang maupun berat.

Keterbatasan penelitian ini ialah antara lain: pengambilan data penelitian tidak dapat dilakukan melalui wawancara langsung, namun kuesioner yang digunakan telah dikonversi dalam google form yang kemudian didistribusikan pada responden lewat grup Whatsapp tiap angkatan. Masa pandemi Covid-19 ini mengharuskan mahasiswa untuk melaksanakan perkuliahan online pun dalam rangka mentaati kebijakan social distancing sehingga tidak dapat dilakukan pengambilan data secara langsung. Selain itu, dalam pengambilan data karakteristik responden, salah satu data yang ditanyakan yaitu berat dan tinggi badan untuk mengukur IMT dari responden, namun hal ini terhalang karena tidak dapat dilakukan secara tatap muka sehingga penulis tidak dapat mengukur secara langsung baik berat maupun tinggi responden dengan menggunakan alat yang baku. Terdapat kemungkinan bahwa data yang didapatkan kurang akurat karena pengukuran dilakukan sendiri oleh responden menggunakan instrumen yang berbeda.

\section{SIMPULAN}

Pada masa pandemi Covid-19 terdapat hubungan bermakna antara body image dengan pengetahuan gizi, pola konsumsi, dan aktivitas fisik pada mahasiswa Peminatan Geotermal Jurusan Fisika Fakultas MIPA Universitas Negeri Manado. Disarankan bagi para mahasiswa agar dapat mempertahankan aktivitas fisik yang dilakukan, serta memperhatikan pola konsumsi dan pengetahuan gizi terutama di masa pandemi Covid-19.

\section{Konflik Kepentingan}

Penulis menyatakan tidak terdapat konflik kepentingan dalam studi ini.

\section{DAFTAR PUSTAKA}

1. Cash TF. Cognitive-Behavioral Perspectives on Body Image. Encyclopedia of Body Image and Human Appearance. 2012;1. Available from: https://doi.org/10.1016/ B978-0-12-384925-0.00054-7

2. Swami V, Horne G, Furnham A. COVID-19related stress and anxiety are associated with negative body image in adults from the United Kingdom. 2021 [cited 2021 July 18]. Available from: https://www. ncbi.nlm.nih.gov/pmc/articles/PMC753 9826/

3. Maryam S, Ifdil I. Relationship between body image and self-acceptance of female students. JAIPTEKIN. 2019;3(3):12936. Available from: https://doi.org/10. 24036/ 4.23280

4. Almatsier S. Prinsip Dasar Ilmu Gizi. Jakarta: PT Gramedia Pustaka Utama; 2010.

5. Korn L, Gonen E, Shaked Y, Golan M. Health perceptions, self and body image, physical activity and nutrition among undergraduate students in Israel. Plos One. 2013;8(3):e58543. Available from: https:// dx.doi.org/10.1371\%2Fjournal. pone. 0058543

6. Dissen AR, Policastro P, Quick V, ByrdBredbenner C. Interrelationships among nutrition knowledge, attitudes, behaviors and body satisfaction. Emerals 
Insight. 2011;111(4):283-95. Available from: https://doi.org/10.1108/09654281 111144256

7. Amissah CM, Nyarko K, Gyasi-Gyamerah AA, Anto-Winne MN. Relationships among body image, eating behavior, and psychological health of University of Ghana Students. International Journal of Humanities and Social Science. 2015 [cited 2021 July 20]. Available from: http://ugspace.ug.edu.gh/handle/12345 $6789 / 27654$

8. Shang Y, Xie HD, Yang SY. The relationship between physical exercise and subjective well-being in college students: the mediating effect of body image and selfesteem. Frontiers in Psychology. 2021; 12:658935. Available from: //dx.doi.org /10.3389\%2Ffpsyg.2021.658935

9. Asci FH. The effects of step dance on physical self-perception of female and male university students. Int J Sport Psychol. 2002;33(4):431-42. Doi: 10.1080/0020 7590244000124

10. Sari D. Peran adaptif tiga universitas di Jabodetabek dalam menghadapi sistem belajar online selama pandemi COVID19. Prosiding Seminar Nasional Hardiknas. 2020 [cited 2021 July 21]. Available from: http://proceedings. ideaspublishing.co.id/index.php/hardik nas/article/view/4/4

11. Arimatea. Dampak-dampak Covid-19 yang dirasakan bagi kehidupan mahasiswa. Universitas Lambung Mangkurat. 2020. Available from: http://dx.doi.org/10. 31234/osf.io/tkqfx

12. Di Renzo L, Gualtieri P, Pivaro F, Soldati L, Attina A, Cinelli G, et al. Eating habits and lifestyle changes during COVID-19 lockdown: an Italian survey. J Transl Med. 2020;18(229). Available from: https://doi.org/10.1186/s12967-020-023 99-5

13. Naja F, Hamadeh R. Nutrition amid the COVID-19 pandemic: a multi-level frameworl for action. PubMed. 2020; 74(8):1117-1121. Available from: https: //doi.org/10.1038/s41430-020-0634-3

14. Tobelo CD, Malonda NSH, Amisi MD. Gambaran pola makan pada mahasiswa semester VI Fakultas Kesehatan Masyarakat Universitas Sam Ratulangi selama masa pandemi COVID-19 [Skripsi]. Manado: Universitas Sam Ratulangi;
2021

15. Gimon NK, Malonda NSH, Punuh MI. 2020. Gambaran stres dan body image pada mahasiswa semester VI Fakultas Kesehatan Masyarakat Universitas Sam Ratulangi selama masa pandemi COVID-19 [Skripsi]. Manado: Universitas Sam Ratulangi; 2020

16. Depkes RI. Klasifikasi Umur Menurut Kategori. Jakarta: Ditjen Yankes; 2009.

17. Ricciardelli LA, Yager Z. Adolescence and Body Image: From Development to Preventing Dissatisfaction. New York: Routledge; 2016.

18. Ardhyarini, Avissa A. Pengaruh pendidikan gizi melalui media website terhadap pengetahuan gizi dan persepsi body image pada remaja putri [Skripsi]. Bandung: Poltekkes Kemenkes Bandung; 2020.

19. Marjan AQ. Relationship between macro nutrients, eating and nutritional knowledge with body image perception in adolescents at senior high school in South Tangerang City. International Conference on Health Development General Papers; 2019.

20. Hyun H, Lee H, Ro Y, Gray HL, Song K. Body image, weight managementa behavior, nutritional knowledge and dietary habits in high school boys in Korea and China. Asia Pac J Clin Nutr. 2017;26(5):92330. Available from: https://doi.org/ 10.6133/apjen.122016.05

21. Grady F, Howard A, McArthur L, Rosenberg R. Knowledge of college students regarding three themes related to dietary recommendations. Am J Health Stud. 2000;16(4):177-84.

22. Solso RL, Maclin OH, Maclin MK. Psikologi Kognitif. Jakarta: Erlangga; 2007.

23. Irwanto. Psikologi Umum. Jakarta: PT Prenhallindo; 2002.

24. Li X, Liu Q. Social media use, ehealth literacy, disease knowledge, and preventive beha-viors in the COVID-19 pandemic: cross-sectional study Chinese netizens. JMIR Publications. 2020;22(10): e19684. Available from: https://doi.org/ $10.2196 / 19684$

25. Tan CC, Ibrahim. Hubungan body image dengan pola makan pada remaja putri. Zona Kebidanan. 2020 [cited 2021 July 20]. Available from: http://ejurnal.univ batam.ac.id/index.php/zonabidan/ 
article/view/695

26. Asnuddin, Sanjaya. Hubungan tingkat kecemasan dan body image dengan pola makan remaja putri di SMA Negeri 2 Sidrap. LPPM STIKES Muhammadiyah Sidrap. 2018. [cited 22 Sept 2021] Available from: https://stikesmusidrap.e-journal.id/JIKP/article/view/31

27. Kaloeti DVS, Ardhiani LN. The effect of selfesteem, attitude towards the body, and eating habit on cognitive reactivity. Jurnal Penelitian Psikologi. 2020;5(1): 57-74. Available from: https://doi.org/ 10.21580/pjpp.v5i1.4561

28. Koftidou L, Davies IG, Jackson A. Investigation between body image, self-esteem and healthy diet. Proceedings of The Nutrition Society. 2011;70. Available from: https://doi.org/10.1017/S002966 5111004708

29. Ura M, Preston KSJ. The influence of thin ideal internalization on women's body image, self-esteem, and appearance. Avoidance: Covariance Structure Analysis. Am Commun J. 2015;17(2):15-26.

30. Johnson F, Wardle J. Dietary restraint, body dissatisfaction, and psychological distress: a prospective analysis. J Abnorm Psychol. 2005;114(1):119-125. Available from: https://doi.org/10.1037/0021 $-843 x .114 .1 .119$

31. Furnham A, Badmin N, Sneade I. Body image dissatisfaction: gender differences in eating attitudes, self-esteem, and rea- sons for exercise. J Psychol. 2002; 136(6):581-596. Available from: https:// doi.org/10.1080/00223980209604820

32. Wood-Barcalow NL, Tylka TL, AugustusHovarth CL. "But I Like My Body": positive body image characteristics and a holistic model for young adult woman. Body Image. 2010;7(2):106-16. Available from: https://doi.org/10.1016/ j. bodyim.2010.01.001

33. Maracilu CN. Hubungan body image terhadap status gizi dan aktivitas fisik pada siswa siswi di SMA Banda Aceh dan Aceh Besar [Skripsi]. Banda Aceh: Universitas Syiah Kuala Darussalam; 2016.

34. Atmaja RG. Hubungan persepsi citra tubuh (body image) dengan aktivitas fisik remaja di SMA Negeri 7 Surakarta [Skripsi]. Surakarta: Universitas Sebelas Maret; 2019.

35. Pop CL. Physical activity, body image, and subjective well-being. Intechopen Wellbeing and Quality of Life. 2017. 10.5772/intechopen.68333

36. Sabiston CM, Pila E, Vani M, ThogersenNtoumani C. Body image, physical activity, and sport: a scoping review. Psychol Sport Exerc. 2019;42:48-57. Available from: https://doi.org/10.1016/ j.psychsport.2018.12.010

37. LePage. Exercise and eating disordered beliefs and behaviors: a study using ecological momentary asssessment [Skripsi]. Ohio: Kent State University; 2011. 